\title{
IMPLEMANTASI LESSON STUDY UNTUK MENINGKATKAN KUALITAS PEMBELAJARAN PADA PERKULIAHAN KESELAMATAN DAN KESEHATAN KERJA MELALUI PENDEKATAN COOPERATIVE LEARNING
}

\author{
Satriyo Agung Dewanto, Slamet, Bekti Wulandari, Ponco Wali Pranoto \\ Prodi Pendidikan Teknik Elektronika, Jurusan Pendidikan Teknik Elektronika FT UNY \\ Email: satriyoad@uny.ac.id
}

\begin{abstract}
ABSTRAK
Penelitian ini bertujuan untuk meningkatkan kualitas pembelajaran pada mata kuliah Keselamatan dan Kesehatan Kerja serta meningkatkan rasa percaya diri, kerjasama,dan tanggungjawab. Peningkatan kualitas pembelajaran ini menerapkan metode pembelajaran problem based learning. Ppenelitian ini menerapkan metod lesson study model Lewis (2002) dan pelaksanaanya dilakukan dalam 3 kegiatan, yaitu: 1) Perencanaan (plan); 2) Pelaksanaan dan Observasi (do); 3) Refleksi (see). Subjek penelitian ini adalah mahasiswa S1 Prodi Pendidikan Teknik Informatika Jurusan Pendidikan Teknik Elektronika dan data diperoleh dengan cara observasi dan perekaman. Hasil penelitian menunjukkan bahwa terjadi peningkatan kualitas proses pembelajaran. Ini dapat dilihat dari jumlah mahasiswa yang aktif semakin banyak, perkuliahan tidak membosankan karena sebagian besar mahasiswa kelihatan antusias dalam belajar. Bagi dosen juga ada keuntungannya yaitu dapat melakukan kolaborasi dengan teman sejawat dalam upaya untuk memperbaiki pembelajarannya. Melalui pembelajaran dengan lesson study ini selain dapat meningkatkan kualitas pembelajaran sekaligus juga dapat menumbuhkan karakter kerja mahasiswa pada mata kuliah Keselamatan dan Kesehatan Kerja. Hal ini terlihat dari tanggung jawab dalam pengambilan keputusan, tidak memisahkan di diri dari orang lain, interaksi terhadap sumber belajar, interaksi antar mahasiswa, aktifitas menyelesaikan masalah dan mahasiswa tidak pasif..
\end{abstract}

Kata kunci: lesson study, kualitas pembelajaran, Cooperative Learning

\section{PENDAHULUAN}

Mata kuliah Keselamatan dan Kesehatan Kerja di Prodi Pendidikan Teknik Informatika Jurusan Pendidikan Teknik Elektronika FT UNY merupakan mata kuliah yang menjamin keutuhan dan kesempurnaan baik jasmani maupun rohani, tenaga kerja pada khususnya dan masyarakat pada umumnya terhadap hasil karya dan budayanya menuju masyarakat adil dan makmur. Secara ilmu pengetahuan dan penerapannya dalam usaha mencegah terjadinya kecelakaan dan penyakit akibat kerja. Tujuan dari mata kuliah ini adalah mengajarkan kepada mahasiswa untuk melindungi kesehatan, keamanan, dan keselamatan dari tenaga kerja, menjamin keamanan alat yang digunakan dan menjamin proses produksi yang aman serta lancar.

FT UNY sebagai salah satu lembaga yang menghasilkan calon guru dan dimungkinkan juga sebagai tenaga kerja di industri sehingga diharapkan mampu mengikuti tuntutan dalam dunia kerja. Di dalam lingkungan kerja selain ketrampilan dan pengetahuan juga dibutuhkan kerjasama (teamwork) untuk menyelesaikan suatu permasalahan. Saat ini, kemampuan tentang K3 peserta didik dalam kebanyakan institusi pendidikan kurang diperhatikan. Menurut Slamet PH (2011), karakter kerja yang dibutuhkan dunia kerja meliputi: etika kerja, rasa keingintahuan, sifat dapat dipercaya, disiplin diri, kejujuran, komitmen, tanggung jawab, respek terhadap diri sendiri dan orang lain, toleransi, kerja keras, hubungan kerja yang baik, integritas, perilaku yang baik, komunikasi kegigihan, motivasi kerja tinggi, kerjasama yang baik, inisiatif, keberanian moral, kerajinan, daya adaptasi, pengendalian diri, pembelajar yang cepat, keinginan untuk belajar hal-hal yang baru, kemampuan cara belajar, keluwesan dan kewirausahaan.

Permasalahan yang dihadapi pada pelaksanaan mata kuliah Keselamatan dan Kesehatan Kerja seperti tersebut diatas perlu diatasi, jika tidak segera diatasi maka mahasiswa disamping akan mengalami kesulitan dalam 
menempuh mata kuliah juga menghambat tumbuhnya sikap kerjasama yang dituntut oleh dunia kerja. Berdasarkan permasalahan diatas, untuk meningkatkan kemandirian mahasiswa dan menumbuhkan sikap kerja sesuai dengan tuntutan dunia kerja maka diperlukan perubahan budaya dalam perkuliahan dari teacher centered learning ke student centered learning. Oleh karena itu perlu dikembangkan model pembelajaran lain dalam mata kuliah Keselamatan dan Kesehatan Kerja untuk mengakomodasi permasalahan di atas. Strategi pembelajaran yang dipilih adalah pembelajaran berbasis Lesson Study dengan mengembangkan dan menerapkan metode cooperative learning.

Lesson Study merupakan bentuk suatu kolaboratif, dasar pengembangan profesional sekolah untuk memperoleh peningkatan dalam pembelajaran dan pengajaran melalui metode professional sharing (David Burghes,2009). Lesson study memberikan banyak kesempatan bagi dosen untuk berkolaborasi dengan sesama sejawat bidang ilmu, sehingga kreatifitas dalam proses pembelajaran dapat merubah prespektif dosen tentang pembelajaran serta untuk belajar melihat proses mengajar yang dilakukan dosen dari prespektif mahasiswa. Lesson Study dilaksanakan melalui tiga tahapan, yaitu Plan (Perencanaan), Do (Pelaksanaan), dan See (Refleksi) (Lewis (2002); Slamet mulyono (2007); kadarisman (2009)). Tiga tahapan ini merupakan satu siklus pembelajaran. Tahapan Plan merupakan perancangan pembelajaran agar mahasiswa dapat belajar dari materi pembelajaran secara aktif.Tahap Do merupakan pelaksanaan pembelajaran yang telah dirancang dalam tahap Plan. Setelah pembelajaran selesai langsung diadakan pertemuan antara Dosen Model dan observer dalam tahap refleksi. Semua orang yang terlibat dalam Lesson Study dapat belajar dari pembelajaran karena pembelajaran tersebut adalah pembelajaran kita. Lesson Study dimaksudkan agar: (a) semua mahasiswa dapat berpartisipasi dalam pembelajaran tanpa kecuali dan (b) Dosen menerapkan hasil yang diperoleh dari refleksi pembelajaran.
Sedangkan Bill Cerbin dan Bryan Kopp dari University of Wisconsin mengetengahkan enam tahapan dalam Lesson Study, yaitu:

a) Form a Team: membentuk tim sebanyak 3-6 orang yang terdiri guru yang bersangkutan dan pihak-pihak lain yang kompeten serta memilki kepentingan dengan Lesson Study. b) Develop Student Learning Goals: anggota tim mendiskusikan apa yang akan dibelajarkan kepada peserta didik sebagai hasil dari Lesson Study. c) Plan the Research Lesson: guru-guru mendesain pembelajaran guna mencapai tujuan belajar dan mengantisipasi bagaimana para peserta didik akan merespons. d) Gather Evidence of Student Learning: salah seorang guru tim melaksanakan pembelajaran, sementara yang lainnya melakukan pengamatan, mengumpulkan bukti-bukti dari pembelajaran peserta didik. e) Analyze Evidence of Learning: tim mendiskusikan hasil dan menilai kemajuan dalam pencapaian tujuan belajar peserta didik. f) Repeat the Process: kelompok merevisi pembelajaran, mengulang tahapan-tahapan mulai dari tahapan ke-2 sampai dengan tahapan ke-5 sebagaimana dikemukakan di atas, dan tim melakukan sharing atas temuantemuan yang ada.

Salah satu metode dalam paradigma konstruktivis adalah cooperative learning adalah kegiatan yang berlangsung dalam lingkungan belajar berbentuk kelompok kecil, sehingga siswa dapat saling berbagi ide dan bekerja secara kolaboratif untuk menyelesaikan tugas akademik (Davidso \& Kroll, 1991:262). Hal tesebut dikuatkan oleh pendapat Arends (2008: 6) bahwa lingkungan cooperative learning mempersiapkan siswa untuk belajar tentang kolaborasi dan berbagai keterampilan social yang sangat berharga yang akan mereka gunakan sepanjang hidupnya.

Manusia adalah makhluk social yaitu makhluk yang tidak bias berdiri sendiri, namun selalu membutuhkan kerja sama dengna orang lain. Jelasnya cooperative learning tidak hanya bertujuan untuk memahamkan siswa terhadap materi yang akan dipelajari namun selalu membutuhkan pada melatih siswa untuk 
mempunyai kemampuan social, yaitu bekerjasama, saling memahami, saling berbagi informasi, saling membantu antar teman kelompok, dan bertanggungjawab terhadap sesame teman kelompok untuk mencapai tujuan umum kelompok.

\section{METODE}

Pendidikan Teknik Informatika Jurusan Pendidikan Teknik Elektronika FT-UNY. Waktu pelaksanaan penelitian ini ditentukan pada perkuliahan semester gasal tahun akademik 2015/2016.

Metode yang diterapkan dalam penelitian ini adalah lesson study model Lewis (2002). Pelaksanaanya dilakukan dalam 3 kegiatan, yaitu: 1) Perencanaan (plan); 2) Pelaksanaan dan Observasi (do); 3) Refleksi (see). Sebelum dilakukan penelitian, diperlukan 2 tahapan persiapan yaitu membentuk kelompok lesson study dan memfokuskan lesson study. Dalam tahap membentuk kelompok ini ditentukan anggota kelompok sebagai tim pengajar sekaligus menentukan seorang dosen dari anggota kelompok sebagai dosen pelaksana pembelajaran (dosen model). Kegiatan dalam tahap kedua memfokuskan lesson study yaitu: menyepakati tentang tema permasalahan, focus permasalahan dan tujuan utama pemecahan masalah, termasuk identifikasi kualitas mahasiswa, kualitas ideal dan kesenjangan yang terjadi; menentukan topik-topiknya.

Setelah tahapan persiapan barulah dilakukan 3 kegiatan lesson study. Pada tahap perencanaan, anggota kelompok menyusun Rencana Pembelajaran (RPP), petunjuk pelaksanaan pembelajaran, serta lembar observasi pembelajaran. Selanjutnya tahap pelaksanaan dan observasi (do). Rencana pembelajaran yang telah disusun bersama diimplementasikan di kelas oleh dosen pelaksana pembelajaran. Anggota kelompok yang lain sebagai observer. Selanjutnya pada tahap terakhir yaitu see, yang digunakan sebagai masukan untuk perbaikan atau revisi rencana pembelajaran berikutnya.

Subjek penelitian ini adalah mahasiswa S1 kelas E Program Studi Pendidikan Teknik Informatika yang mengambil mata kuliah Keselamatan dan Kesehatan Kerja pada semester gasal tahun akademik 2015/2016.

Pengumpulan data dilakukan dengan teknik observasi dan perekaman. Teknik observasi dan perekaman digunakan untuk merekam kualitas pembelajaran. Lembar observasi digunakan untuk mengetahui kualitas pembelajaran Keselamatan dan Kesehatan Kerja. Lembar observasi berisi tentang komponen kegiatan mahasiswa meliputi: tanggung jawab dalam pengambilan keputusan, tidak memisahkan diri dari orang lain, interaksi terhadap sumber belajar, interaksi antar mahasiswa, aktifitas menyelesaikan masalah dan mahasiswa tidak pasif.

Data hasil observasi dianalisis secara deskriptif untuk mengetahui kualitas pembelajaran Keselamatan dan kesehatan Kerja dan tumbuhnya kerjasama dalam menyelesaikan masalah. Analisis data untuk karakter kerja dilakukan secara kualitatif dengan 4 kriteria yaitu :

BT : Belum Terlihat (apabila peserta didik belum memperlihatkan tanda- tanda awal perilaku yang dinyatakan dalam indikator)

MT : Mulai Terlihat (apabila peserta didik sudah mulai memperlihatkan adanya tanda-tanda awal perilaku yang dinyatakan dalam indikator tetapi belum konsisten)

MB : Mulai Berkembang (apabila peserta didik sudah memperlihatkan berbagai tanda perilaku yang dinyatakan dalam indikator dan mulai konsisten)

MM : Mulai Membudaya (apabila peserta didik terus menerus memperlihatkan perilaku yang dinyatakan dalam indikator secara konsisten)

\section{HASIL DAN PEMBAHASAN}

Pertama yang dilakukan dalam penelitian ini adalah observasi. Observasi dilakukan 
sebelum Lesson study dilaksanakan yang digunakan untuk mengetahui kondisi awal proses pembelajaran dan aktivitas mahasiswa sebelum diberikan perlakuan. Dalam observasi ini diperoleh hasil bahwa tanggungjawab mahasiswa dalam mengambil keputusan serta aktivitas dalam menyelesaikan permasalahan yang diberikan belum terlihat.

Selanjutnya, tahapan lesson study dapat dijelaskan sebagai berikut:

\section{Perencanaan (plan)}

Perencanaan (plan) dilakukan dengan cara diskusi sesama peneliti untuk membuat tata cara pelaksanaan, penetapan materi pembelajaran, dan waktu pelaksanaan. Diskusi menghasilkan kesepahaman mengenai rencana tindakan untuk meningkatkan kualitas dan membangun kerja sama mahasiswa melalui pembelajaran berbasis lesson study. Setelah terjadi kesepahaman dilanjutkan diskusi tentang pokok-pokok yang harus dilakukan dalam menyusun rancangan pembelajaran, kemudian menentukan jumlah kelompok dan masingmasing anggota kelompok harus bersifat heterogen dilihat dari segi kemampuan akademiknya. Tugas dosen model selama proses pembelajaran berlangsung adalah menyampaikan tujuan, materi pembelajaran, membagi tugas yang harus dikerjakan oleh mahasiswa dalam kelompok, menyampaikan tata cara mahasiswa bekerja dalam kelompok, mengobservasi mahasiswa dalam kelompok, mengevaluasi kerja mahasiswa, memberi penguatan,dan merangkum materi pembelajaran. Dalam proses pembelajaran akan dilakukan pengamatan kegiatan mahasiswa. Adapun komponen kegiatan mahasiswa yang diamati adalah tanggungjawab dalam pengambilan mahasiswa, tidak memisahkan diri dari orang lain, interaksi terhadap sumber belajar, interaksi antar mahasiswa, rasa keingintahuan, aktivitas menyelesaikan masalah, mahasiswa pasif (misalnya melamun, topang dagu, dsb).

Langkah selanjutnya adalah melakukan perencanaan pelaksanaan perkuliahan diantaranya dengan membagi mahasiswa menjadi 8 kelompok yang masing-masing kelompok terdiri dari 4 mahasiswa. Masingmasing kelompok diwajibkan menyelesaikan materi dengan cara yang yang kemungkinan bisa berbeda. Selain perencanaan tersebut, tim peneliti membua trancangan pembelajaran dengan menekankan: (1) semua mahasiswa diwajibkan menyiapkan sumber belajar untuk praktikum,(2) diminta untuk berpakaian lebih rapi menggunakan baju praktikum, (3) menekankan kerjasama antaranggota kelompok dalam menyelesaikan masalah.

2. Pelaksanaan dan Observasi (Do)

Kegiatan pembelajaran diorientasikan pada aktivitas mahasiswa dalam bekerjasama antar kelompok. Dalam kegiatan pelaksanaan dan observasi, dosen model melakukan penyelenggaraan PBM dan observer melakukan observasi dengan mencatat apa saja yang diamati saat proses pembelajaran berlangsung sesuai poin-poin yang telah tersedia dalam lembar observasi. Mengawali pekuliahan dosen menyampaikan tujuan pembelajaran dan topik yang akan dibahas. Setelah itu membagi mahasiswa menjadi 5 kelompok dengan anggota kelompok terdiri dari 4 mahasiswa. Selanjutnya mahasiswa berdiskusi secara berkelompok untuk menyelesaikan tugas yang diberikan di bawah bimbingan dosen. Dalam hal ini dosen tidak serta merta membiarkan mahasiswa tetapi tetapi menjadi fasilitator. Observer mengamati dan mencatat aktivitas mahasiswa dalam lembar observasi dan melakukan perekaman. Selanjutnya, mahasiswa mempresentasikan hasil praktikumnya di depan kelas dan dosen melakukan rangkuman guna menguatkan materi. 3. Refleksi (see)

Setelah perkuliahan selesai maka dilakukan refleksi atas jalannya perkuliahan. Observer dan dosen model membahas kelebihan dan kekurangan yang terjadi selama perkuliahan berlangsung. Hasil pengamatan kegiatan mahasiswa dalam PBM dan karakter mahasiswa adalah sebagai berikut: 
Tabel 1. Hasil Refleksi

\begin{tabular}{|c|c|c|c|c|c|c|c|c|c|}
\hline \multirow[t]{2}{*}{ No } & \multirow[t]{2}{*}{ Aspek pengamatan } & \multicolumn{8}{|c|}{ Kelompok } \\
\hline & & 1 & 2 & 3 & 4 & 5 & 6 & 7 & 8 \\
\hline \multicolumn{10}{|c|}{ Kerjasama } \\
\hline 1 & $\begin{array}{l}\text { Tanggungjawab } \\
\text { dalam pengambilan } \\
\text { keputusan }\end{array}$ & MB & MM & MM & MM & MM & MB & MM & MM \\
\hline 2 & $\begin{array}{l}\text { Interaksi antar } \\
\text { mahasiswa }\end{array}$ & MB & MM & MM & MB & MM & MB & MM & MM \\
\hline 3 & $\begin{array}{l}\text { Interaksi terhadap } \\
\text { sumber belajar }\end{array}$ & MM & MM & MM & MM & MM & MM & MM & MM \\
\hline 4 & $\begin{array}{l}\text { Mahasiswa tidak } \\
\text { aktif }\end{array}$ & MB & MM & MM & MM & MM & MB & MM & MM \\
\hline 5 & $\begin{array}{l}\text { Mahasiswa diam } \\
\text { karena berfikir dan } \\
\text { perhatian }\end{array}$ & MB & MM & MM & $\mathrm{MB}$ & $\mathrm{MB}$ & $\mathrm{MB}$ & $\mathrm{MB}$ & MM \\
\hline 6 & $\begin{array}{l}\text { Mahasiswa } \\
\text { menyampaikan } \\
\text { pendapat }\end{array}$ & MM & MM & MM & MM & MM & MM & $\mathrm{MM}$ & MM \\
\hline 7 & $\begin{array}{l}\text { Mahasiswa percaya } \\
\text { diri }\end{array}$ & MM & MM & MM & MM & MM & MB & MM & MM \\
\hline 8 & $\begin{array}{l}\text { Kerjasama antar } \\
\text { kelompok }\end{array}$ & MB & MM & MM & $\mathrm{MB}$ & MM & $\mathrm{MB}$ & $\mathrm{MM}$ & $\mathrm{MM}$ \\
\hline
\end{tabular}

Dari Tabel 1 tampak bahwa secara umum telah terjadi peningkatan kualitas pembelajaran pada mata kuliah Keselamatan dan Kesehatan Kerja. Kenyataan ini terlihat dari aktivitas mahasiswa yang lebih aktif dalam mengikuti pembelajaran. Sehingga jumlah mahasiswa yang pasif menurun dan mulai berkembang (MB) untuk tidak pasif. Interaksi antar mahasiswa dalam satu kelompok sudah meningkat. Kualitas pembelajaran sudah meningkat dan terlihat dari aktivitas mahasiswa yang lebih aktif dalam mengkuti pembelajaran. Aktivitas mahasiswa meningkat ke dalam taraf Mulai Berkembang (MB) dan Membudaya (MM). Perilaku saat diskusi kelompok semakin kompak, mahasiswa lebih mengembangkan analisisnya dengan kesiapan sumber belajar yang lebih baik yang tergolong dalam Membudaya (MM). Kerjasama mahasiswapun sudah ada menunjukkan ke arah yang lebih baik, dimana mulai Membudaya (MM) tanggungjawab dalama pengambilan keputusan dan Mulai Berkembang (MB) aktivitas mahasiswa dalam bentuk kerjasama.

Secara keseluruhan dari pelaksanaan lesson study yang dilakukan menunjukkan bahwa terjadi peningkatan kualitas proses pembelajaran dan peningkatan kemampuan kerjasama tim. Ini dapat dilihat dari perkuliahan tidak membosankan karena sebagian besar mahasiswa kelihatan antusias dalam belajar. Bagi dosen juga ada keuntungannya yaitu dapat melakukan kolaborasi dengan teman sejawat dalam upaya untuk memperbaiki pembelajarannya. Walaupun penelitian ini menunjukkan hasil yang baik, tetapi untuk mengubah perilaku belajar bukanlah hal mudah. Maka dari itu perlu adanya keberlanjutan pelaksanaan metode ini meskipun tidak sama persis setidaknya 
pola perilaku yang telah dibangun dapat dipertahankan.

\section{SIMPULAN}

\begin{abstract}
Berdasarkan hasil dan pembahasan yang telah dipaparkan di atas, maka dapat disimpulkan sebagai berikut:
\end{abstract}

1. Diperoleh pola pembelajaran berbasis lesson study pada mata kuliah Keselamatan dan Kesehatan Kerja untuk meningkatkan kualitas proses belajar mahasiswa, yaitu:

a. Sebelum perkuliahan berlangsung, dosen dan kolaborator menyiapkan perencanaan untuk pembelajaran yaitu materi kuliah, RPP, dan lembar observasi.

b. Pelaksanaan perkuliahan diawali dengan penjelasan dosen tentang materi yang akan dipraktikkan dan permasalahan yang akan diselesaikan. Kemudian dilakukan pemecahan masalah secara kelompok dan kemudian dilanjutkan dengan presentasi kelompok di depan kelas. Pada pelaksanaan perkuliahan dilakukan observasi dan pengamatan untuk mengetahui kekurangan proses pembelajaran.

c. Setelah perkuliahan selesai dilakukan refleksi untuk mengurangi kelemahan yang terjadi dalam proses pembelajaran. Sehingga dapat meningkatkan proses pembelajaran.

2. Melalui pembelajaran dengan lesson study ini selain dapat meningkatkan kualitas pembelajaran sekaligus juga dapat menumbuhkan karakter kerja mahasiswa pada mata kuliah Keselamatan dan Kesehatan Kerja pada aspek kerjasama, tanggungjawab, dan rasa percaya diri..

\section{DAFTAR RUJUKAN}

Arends, Richard. I. (2008). Belajar untuk mengajar. Edisi ke tujuh alih bahasa oleh helly prayitno dan sri mulyantani prayitnodari judul

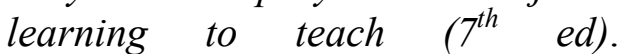
Yogyakarta : Penerbit Pustaka Pelajar.

Bill Cerbin \& Bryan Kopp. A Brief Introduction to College Lesson Study. Lesson Study Project. online: http://www.uwlax.edu/sotl/1sp/index 2.htm

Davidson, N 7 Kroll, D.L. (1991). An Overview of Research On Cooperative Learning.

Departemen Pendidikan Nasional. (2002). Kamus Besar Bahasa Indonesia. Jakarta: Balai Pustaka.

Eggen, P.D. \& Kauchak, P.P (1998). Strategies for Teacher: Teaching Content and Thinking Skill. Boton: Alyn \& Bacon.

Lewis, Catherine C. (2002), Lesson Study : A Handbook of Teacher-Led Instructional Change, Philadelphia, PA : research for better Schools, Inc.

Related to Mathematics. Journal for research in Mathematics Education. 22(5):362-365.

Republik Indonesia. 2003. Undang-undang Nomor 20 Tahun 2003 Tentang Sistem Pendidikan Nasional. Jakarta:Setneg

Republik Indonesia. 2005. Undang-undang Nomor 19 Tentang Badan Standar Nasional Pendidikan. Jakarta:Departemen Pendidikan Nasional.

Rusman. (2012). Model-model pembelajaran mengembangkan profesional guru. Jakarta : Raja Grafindo Persada.

Slavin, R.E. (1995). Cooperative Learning, second edition. Massachusets: Allyn \& Bacon. 
Tantra, D.K. (2005). Peningkatan Profesionalisme Guru dengna Paradigma Baru (makalah disampaikan dalam workshop menumbuhkan komitmen guru dan pegawai SMA Negeri 3 Denpasar, pada tanggal 3 Januari 2005 di Cndikuning Tabanan)

Uhar Suharsaputra. (2010). Administrasi Pendidikan. Bandung: Refika Aditama.

Wina Sanjaya. (2008). Strategi Pembelajaran Berorientasi Standar Proses Pendidikan Jakarta: Kencana Prenada Media. 